\title{
Evaluation of Container Ornamental Species Tolerance to Three $p$-hydroxyphenylpyruvate Dioxygenase-inhibiting Herbicides
}

\author{
Matthew A. Cutulle ${ }^{1,3,10}$, Gregory R. Armel ${ }^{1,4}$, James T. Brosnan ${ }^{1,4}$, \\ Dean A. Kopsell ${ }^{1,5}$, William E. Klingeman ${ }^{1,6}$, Phillip C. Flanagan ${ }^{1,7}$, \\ Gregory K. Breeden ${ }^{1,7}$, Jose J. Vargas ${ }^{1,8}$, Rebecca Koepke-Hill ${ }^{1,9}$, \\ and Mark A. Halcomb ${ }^{2}$
}

\section{ADDITIONAL INDEX WORDS. bleaching herbicides, nursery production}

SUMMARY. Selective weed control in ornamental plant production can be difficult as many herbicides can cause unacceptable injury. Research was conducted to evaluate the tolerance of several ornamental species to applications of $p$-hydroxyphenylpyruvate dioxygenase (HPPD)-inhibiting herbicides for the control of problematic weeds in ornamental production. Mestotrione $(0.09,0.18$, and $0.36 \mathrm{lb} / \mathrm{acre})$, tembotrione $(0.08,0.16$, and $0.32 \mathrm{lb} /$ acre $)$, and topramezone $(0.016,0.032$, and 0.064 $\mathrm{lb} /$ acre) were applied alone postemergence (POST) in comparison with the photosystem II-inhibiting herbicide, bentazon $(0.5 \mathrm{lb} /$ acre $)$. All herbicide treatments, with the exception of the two highest rates of tembotrione, caused less than 8\% injury to 'Noble Upright' japanese holly (Ilex crenata) and 'Compactus' burning bush (Euonymus alatus). Similarly, no herbicide treatment caused greater than $12 \%$ injury to 'Girard's Rose' azalea (Azalea). Conversely, all herbicides injured flowering dogwood (Cornus flovida) $10 \%$ to $23 \%$. Mesotrione- and tembotrioneinjured 'Radrazz' rose (Rosa) $18 \%$ to $55 \%$, compared with only $5 \%$ to $18 \%$ with topramezone. 'Siloam June Bug' daylily (Hemerocallis) injury with topramezone and tembotrione was less than $\mathbf{1 0 \%}$. Topramezone was the only herbicide evaluated that provided at least $93 \%$ control of redroot pigweed (Amaranthus retroflexus) with all application rates by 4 weeks after treatment (WAT). Redroot pigweed was controlled $67 \%$ to $100 \%$ with mesotrione and tembotrione by 4 WAT, but this activity was variable among application rates. Spotted spurge (Chamaesyce maculata) was only adequately controlled by mesotrione applications at 0.18 and $0.36 \mathrm{lb} /$ acre, whereas chamberbitter (Phyllanthus urinaria) was not controlled sufficiently with any herbicide evaluated in these studies. Yellow nutsedge (Cyperus esculentus) was suppressed $72 \%$ to $87 \%$ with mesotrione applications at $0.18 \mathrm{lb} /$ acre or higher and with bentazon at $0.5 \mathrm{lb} /$ acre by 4 WAT. All other herbicide treatments provided less than $58 \%$ control of yellow nutsedge. In the second study, 'Patriot' hosta (Hosta), 'Green Sheen' pachysandra (Pachysandra terminalis), autumn fern (Dryopteris erythrosora), 'Little Princess' spirea (Spiraea japonica), 'Green Giant' arborvitae (Thuja plicata), and 'Rosea' weigela (Weigela flovida) displayed no response to topramezone when applied at 0.024 and $0.095 \mathrm{lb} / \mathrm{acre}$. Since 10 ornamental species in our studies exhibited less than $10 \%$ herbicidal response with all rates of at least one HPPD-inhibiting herbicide then it is possible that these herbicides may provide selective POST weed control in ornamental production systems.

$\longrightarrow$ ontrolling weed contamination in nursery stock is difficult in ornamental production. Although cultural practices for weed control in nurseries include mulching and the use of fabrics to impede the development of emerging weeds, these techniques are not completely effective in the absence of a chemical control (Case et al., 2005; Mathers and Ozkan, 2001). Acetyl-CoA carboxylase inhibitors are effective at remedially managing grasses in dicotyledonous nursery stock (Senesac, 2002); however, selective control of broadleaf weeds in ornamental systems is more difficult. In part, challenges derive in that both broadleaf weeds and many desirable ornamentals are both dicotyledonous species with variable sensitivity to postemergence herbicides (Case et al., 2005; Derr, 1994).

To date, there are few POST herbicides registered for selective broadleaf control in ornamental plants. These herbicides do not provide broad-spectrum broadleaf weed control in ornamental production and/or are not registered for use over the top of many ornamental species.
Mesotrione, topramezone, and tembotrione are herbicides that inhibit the HPPD enzyme. These herbicides impede the production of plastoquinone in susceptible species, ultimately preventing the production of photoprotective carotenoid compounds. As a result, the plant's ability to sequester singlet- and triplet-state oxygen and dissipate excess photosynthetic active radiation is compromised (Niyogi, 1999). Eventually foliar plant tissue becomes bleached, necrotic, and photosynthetically inactive resulting in plant death. Mesotrione, topramezone, and tembotrione are labeled for weed control in corn (Zea mays) and multiple turfgrass species (Elmore et al., 2011; Gettys and Haller, 2009). Weeds controlled by these herbicides include (but are not limited to) common cocklebur (Xanthium strumarium), common lambsquarters (Chenopodium album), smartweed species (Polygonum sp.), common ragweed (Ambrosia artemisiifolia), yellow nutsedge, nimblewill (Mublenbergia schreberi), and crabgrass (Digitaria sp.) (Beam et al., 2006; Giese et al., 2005; Jones and Christians, 2007; Senseman, 2007; Willis et al., 2006).

Several researchers have reported moderate injury $(<45 \%)$ to burning bush, vinca (Vinca sp.), and loblolly pine (Pinus taeda) with mesotrione applications (Jackson et al., 2009; Little et al., 2004; Senesac and TsontakisBradley, 2007). Other researchers (Vea and Palmer, 2010) showed that mesotrione applications caused unacceptable phytotoxicity to over 20 ornamental plant species. However, data describing ornamental tolerance to topramezone and tembotrione are minimal. Thus, our objective was to determine ornamental tolerance and weed control efficacy with applications of the HPPD-inhibiting herbicides mesotrione, tembotrione, and topramezone compared with bentazon, an important ornamental herbicide on common ornamental plant and weed species in Tennessee.

\section{Materials and methods}

Site Description. Two studies were conducted in a shadehouse structure at the University of Tennessee (Knoxville, lat. $35.9465^{\circ} \mathrm{N}$, long. $83.9386^{\circ} \mathrm{W}$ ) evaluating ornamental tolerance and weed control efficacy with mesotrione, tembotrione, and 
topramezone compared with the commercial standard bentazon. Study 1 was conducted from 3 July 2008 until 3 Aug. and then repeated from 4 Aug. until 4 Sept. Maximum/minimum air temperature during this period averaged $88 / 66{ }^{\circ} \mathrm{F}$ and accumulated growing degree days during this time was 848 (base temperature $50{ }^{\circ} \mathrm{F}$ ). Study 2 was conducted from 2 Aug. 2009 until 16 Sept. 2009 and repeated from 9 Aug. until 23 Sept. Maximum/ minimum air temperature during this time was $84 / 64{ }^{\circ} \mathrm{F}$ and accumulated growing degree days during this time was 866 (base temperature $50^{\circ} \mathrm{F}$ ).

STUDY 1. The ornamental species were chosen for these studies based on their value to the nursery industry in Tennessee (Jackson et al., 2008; Johnson et al., 1976; Smith and McConnel, 1978). For the first study, ornamental species included trade-grown 'Siloam June Bug' daylily, 'Girard's Rose' azalea, and Knock Out $^{\mathrm{TM}}$ 'Radrazz' rose, as well as plants propagated on campus including flowering dogwood seedlings, 'Compactus' burning bush and 'Noble Upright' japanese holly from rooted cuttings. Redroot pigweed, chamberbitter, spotted spurge, and yellow nutsedge were also included in this study as they are problematic weeds of ornamental production (Atland et al., 2003; Gilliam et al., 1990; Norcini and Stamps, 1994). A 1/4-teaspoon was filled with weed seeds of a specific species and the seeds were dispersed

We would like to acknowledge Joe Beeler, Douglas Renfro, Jake Huffer and Greg Allen for their assistance in treatment, maintenance and data collection of the experiments. Their contributing effort was greatly appreciated. We would also like to thank Dupont Crop Protection, Syngenta Professional Products, Bayer CropScience, and BASF Corporation for providing herbicide samples. We appreciate Oak Grove Nursery (Belvidere, TN), Cumberland Nursery (Smithville, TN), Kinsey Gardens (Knoxville, TN), and Holden Nursery (Mascot, TN) for assisting us to secure the plants needed for our trials.

${ }^{1}$ Department of Plant Sciences, The University of Tennessee, 2431 Joe Johnson Drive, 252 Ellington Plant Sciences Building, Knoxville, TN 37996

${ }^{2}$ Area Nursery Specialist, University of Tennessee Extension, 201 Locust Street, Suite 10, McMinnville, TN 37110

${ }^{3}$ Post-Doctoral Researcher

${ }^{4}$ Assistant Professor

${ }^{5}$ Associate Professor

${ }^{6}$ Professor

${ }^{7}$ Research Associate

${ }^{8}$ Research Assistant

${ }^{9}$ Extension Assistant

${ }^{10}$ Corresponding author. E-mail: mcutulle@utk.edu. equidistant from one another. All weed species in this first study were established from seed in 1-gal blowmolded containers (Nursery Supplies, Chambersburg, PA). Weeds were treated with herbicides 6 weeks after seeding.

All ornamental and weed species were treated with the HPPD-inhibitors mesotrione (Tenacity ${ }^{\circledR}$; Syngenta Professional Products, Greensboro, NC), tembotrione (Laudis ${ }^{\circledR}$; Bayer Crop Science, Research Triangle Park, NC), and topramezone $\left(\right.$ Impact $^{\circledR} ;$ Amvac Chemical Corp, Los Angeles, CA). Three rates of mesotrione $(0.09$, 0.18 , and $0.36 \mathrm{lb} /$ acre $)$, tembotrione $(0.08,0.16$, and $0.32 \mathrm{lb} /$ acre $)$, and topramezone $(0.016,0.032$, and $0.064 \mathrm{lb} / \mathrm{acre}$ ) were applied. These rates encompassed the labeled rate ranges in pounds of active ingredient per acre for topramezone, tembotrione, and mesotrione in corn and fine turf. For comparison, bentazon was also applied at $0.5 \mathrm{lb} /$ acre a.i. In all studies, herbicide treatments included crop oil concentrate (Agridex; Helena Chemical Corp., Memphis, $\mathrm{TN}$ ) at $1 \% \mathrm{v} / \mathrm{v}$. Treatments were applied with a water carrier using a carbon dioxide-powered backpack sprayer calibrated to deliver $23 \mathrm{gal} / \mathrm{acre}$. A fournozzle boom with 8002 flat fan nozzles (TeeJet; Spraying Systems Corp., Wheaton, IL) spaced 18 inches apart was pressurized at $60 \mathrm{psi}$ to deliver the spray solution. Irrigation was withheld for $24 \mathrm{~h}$ following all herbicide treatments.

STUDY 2. Topramezone is the first pyrazolone herbicide that has the potential to be labeled in ornamental production (Senseman, 2007). Thus, a second study was conducted to generate additional data on ornamental tolerance to topramezone applications. Ornamental species in the second study consisted of kousa dogwood (Cornus kousa) seedlings and 'Lynwood Gold' border forsythia (Forsythia Xintermedia), 'Scarlet Curls' hankow willow (Salix matsudana),
'Dark Knight' butterfly bush (Buddleia davidii), and 'Green Sheen' pachysandra plants that were propagated on campus from rooted cuttings, as well as trade-grown, l-gal containerized 'Patriot' hosta, autumn fern, 'May Night' salvia (Salvia officinalis), 'Little Princess' spirea, 'Green Giant' arborvitae, and 'Rosea' weigela in 3-gal nursery containers.

The application equipment used in Study 2 was the same as was used in Study l. In the second study, topramezone was evaluated POST at 0.024 and $0.095 \mathrm{lb} /$ acre alone in comparison with bentazon at $1.0 \mathrm{lb} /$ acre. To better characterize topramezone tolerance for ornamental plant production, a larger number of species were accessed in the second experiment with a higher rate of topramezone than was applied in the first experiment.

Plant propogation. For both studies, propagated plant materials were maintained in a greenhouse during Spring 2008 and 2009. Mean greenhouse air temperatures during the 1 -month propagation period was $68^{\circ} \mathrm{F}$. Irrigation was supplied by mist at $8 \mathrm{~s}$ on duration with 10 -min intervals from 0800 to $2000 \mathrm{HR}$. Once rooted, ornamental plants were transplanted from propagation trays and grown in a shadehouse for an additional 2 months in separate 1 -gal blowmolded containers (Nursery Supplies) filled with $100 \%$ aged pine bark media with fines (Smith Garden Products, Cumming, GA). Particle size distribution of the soilless substrate was not recorded. No sand or micronutrients were added at time of transplanting, but 1 week before herbicide treatment, all containers were fertilized with the low label rate $(8 \mathrm{~g}$ per 1 -gal container, $23 \mathrm{~g}$ per 3 -gal container) of $14 \mathrm{~N}-6.1 \mathrm{P}-11.6 \mathrm{~K}$ controlled-release fertilizer (Osmocote Classic 14-1414,3 to 4 -month release rate; Everris International, Geldermalsen, The Netherlands). Overhead irrigation to container plants was supplied to

\begin{tabular}{llll}
\hline $\begin{array}{l}\text { To convert U.S. to SI, } \\
\text { multiply by }\end{array}$ & U.S. unit & SI unit & $\begin{array}{l}\text { To convert SI to U.S., } \\
\text { multiply by }\end{array}$ \\
\hline 3.7854 & gal & $\mathrm{L}$ & 0.2642 \\
2.54 & inch $(\mathrm{es})$ & $\mathrm{cm}$ & 0.3937 \\
1.1209 & lb/acre & $\mathrm{kg} \cdot h{ }^{-1}$ & 0.8922 \\
28.3495 & $\mathrm{oz}$ & $\mathrm{g}$ & 0.0353 \\
6.8948 & $\mathrm{psi}$ & $\mathrm{kPa}$ & 0.1450 \\
4.9289 & teaspoon & $\mathrm{cm}^{3}$ & 0.2029 \\
$\left({ }^{\circ} \mathrm{F}-32\right) \div 1.8$ & ${ }^{\circ} \mathrm{F}$ & ${ }^{\circ} \mathrm{C}$ & $\left({ }^{\circ} \mathrm{C} \times 1.8\right)+32$
\end{tabular}


maintain active growth by hand during the duration of the study.

Ornamental plant injury was visually assessed 2 and 4 WAT. Injury was visually assessed in both studies using a $0 \%$ (i.e., no injury) to $100 \%$ (i.e., no healthy tissue visible/complete necrosis) scale relative to a nontreated control. Greater than 10\% injury to the ornamental plant may be undesirable for immediate sale of the plant and would be considered undesirable injury in an ornamental landscape. Weed control for each species was assessed at 4 WAT using a similar $0 \%$ to $100 \%$ scale relative to a nontreated control. Greater than $80 \%$ weed control may be considered acceptable. At 4 WAT all aboveground vegetation for each weed species was removed from the pine bark and oven-dried at $262^{\circ} \mathrm{F}$ for $48 \mathrm{~h}$ then weighed in Study 1.

All studies were designed as randomized complete blocks with three replications and repeated in time. Arcsine transformations were performed on visual ratings before analysis of variance using mixed model methodology in SAS (version 9.2; SAS Institute, Cary, NC). Herbicide treatment was considered a fixed effect, while replication was considered random. The Shapiro-Wilk diagnostic value of normality assessments of nontransformed means was acceptable and interpretations of arcsine and nontransformed data did not differ. Therefore, nontransformed means are presented for clarity. Treatment means in each study were separated using Fisher's protected least significant difference test $(\alpha=0.05)$. Data were pooled across experimental runs when no run-by-treatment interactions occurred.

\section{Results and discussion}

STUDY 1. Ornamental plant injury varied because of herbicide treatment in the first study (Table 1). Mesotrione injured daylily $3 \%$ to $27 \%$ by 2 WAT with up to $10 \%$ injury still visible by 4 WAT. Azalea and burning bush were injured $2 \%$ to $8 \%$ from mesotrione applications by 2 WAT, but this response was not visible by 4 WAT. Japanese holly was never injured greater than $5 \%$ by any mesotrione treatment. Applications of mesotrione resulted in unacceptable injury to flowering dogwood and rose. Applying mesotrione at $0.36 \mathrm{lb} /$ acre resulted in $55 \%$ injury to rose, which was the most observed on any ornamental species in these studies. Vea and Palmer (2010) had previously reported that applications of mesotrione was injurious to many ornamental plants evaluated in their study, thus the injury observed to rose in this study was not surprising.

With the exception of flowering dogwood and rose, application of tembotrione at $0.08 \mathrm{lb} /$ acre resulted in minimal injury $(0 \%$ to $8 \%)$ to all ornamentals in the first experiment (Table 1). Flowering dogwood and rose injury ranged from $10 \%$ to $33 \%$ regardless of tembotrione rate. Few differences in injury were detected by increasing the application rate of tembotrione to $0.32 \mathrm{lb} /$ acre; however, this increase in application rate did result in $10 \%$ to $20 \%$ injury to burning bush, azalea, and daylily by 4 WAT.

Topramezone at all rates resulted in less than $8 \%$ injury to daylily, burning bush, and japanese holly in the first study (Table 1). No differences in azalea injury were detected between topramezone rates; injury ranged from $5 \%$ to $12 \%$ by 4 WAT. Topramezone was the safest HPPDinhibiting herbicide evaluated on flowering dogwood and roses; however, $17 \%$ to $20 \%$ injury was still observed with the highest rate evaluated by 4 WAT. Topramezone is in the pyrazolone family, whereas mesotrione and tembotrione are in the triketone family. Structural differences between pyrazolone and triketone herbicides likely impact uptake, translocation, metabolism, or binding at the herbicide target site differently for multiple species. Previous research indicates that tolerance to HPPD-inhibiting herbicides is a function of both herbicide metabolism and a decreased affinity of the herbicide to the HPPD enzymes in tolerant plants (Grossman and Ehrhardt, 2007). Therefore, a different spectrum of ornamental plants might be more tolerant to topramezone than was observed with mesotrione and tembotrione.

STUDY 2. In the second topramezone specific study, hosta, pachysandra, autumn fern, spirea, arborvitae, and weigela displayed no response to topramezone when applied at 0.024 and $0.095 \mathrm{lb} /$ acre by 4 WAT (Table 2 ).

Table 1. Effects of herbicide treatment on tolerance to six ornamental plant species in a shadehouse study at Knoxville, TN in 2008.

\begin{tabular}{|c|c|c|c|c|c|c|c|c|c|c|c|c|c|}
\hline \multirow[b]{4}{*}{ Treatment } & \multirow[b]{4}{*}{ Rate $(1 \mathrm{~b} / \text { acre })^{\mathrm{z}}$} & \multicolumn{12}{|c|}{ Ornamental injury $(\%)^{y}$} \\
\hline & & \multicolumn{2}{|c|}{ Daylily } & \multicolumn{2}{|c|}{ Burning bush } & \multicolumn{2}{|c|}{ Azalea } & \multicolumn{2}{|c|}{ Japanese holly } & \multicolumn{2}{|c|}{ Flowering dogwood } & \multicolumn{2}{|c|}{ Rose } \\
\hline & & \multicolumn{10}{|c|}{ Weeks after treatment } & & \\
\hline & & 2 & 4 & 2 & 4 & 2 & 4 & 2 & 4 & 2 & 4 & 2 & $\overline{4}$ \\
\hline Mesotrione & 0.090 & 12 & 3 & 2 & 0 & 8 & 0 & 3 & 0 & 13 & 17 & 37 & 23 \\
\hline Mesotrione & 0.180 & 27 & 10 & 2 & 0 & 3 & 0 & 5 & 3 & 10 & 18 & 37 & 35 \\
\hline Mesotrione & 0.360 & 3 & 2 & 2 & 0 & 2 & 0 & 3 & 5 & 10 & 8 & 23 & 55 \\
\hline Topramezone & 0.016 & 0 & 2 & 3 & 7 & 7 & 5 & 3 & 0 & 10 & 20 & 15 & 5 \\
\hline Topramezone & 0.032 & 3 & 0 & 5 & 7 & 5 & 10 & 3 & 0 & 13 & 17 & 8 & 7 \\
\hline Topramezone & 0.064 & 7 & 2 & 0 & 7 & 3 & 12 & 5 & 0 & 18 & 20 & 18 & 17 \\
\hline Tembotrione & 0.080 & 2 & 0 & 0 & 5 & 2 & 8 & 0 & 0 & 15 & 10 & 32 & 20 \\
\hline Tembotrione & 0.160 & 0 & 0 & 2 & 15 & 3 & 5 & 5 & 0 & 10 & 17 & 23 & 18 \\
\hline Tembotrione & 0.320 & 10 & 0 & 8 & 20 & 5 & 12 & 3 & 5 & 18 & 13 & 20 & 33 \\
\hline Bentazon & 0.500 & 0 & 0 & 5 & 8 & 0 & 0 & 0 & 0 & 10 & 10 & 42 & 3 \\
\hline $\operatorname{LSD}_{0.05}{ }^{x}$ & & 7 & 6 & 6 & 9 & 5 & 7 & 6 & 3 & 8 & 13 & 11 & 13 \\
\hline
\end{tabular}

${ }^{\mathrm{z}} \mathrm{l} \mathrm{lb} /$ acre $=1.1209 \mathrm{~kg} \cdot \mathrm{ha}^{-1}$

ynjury was evaluated visually on a $0 \%$ (no injury) to $100 \%$ (complete necrosis) scale relative to a nontreated control for each species.

'Fisher's least significant difference (LSD) at $\alpha=0.05$. 


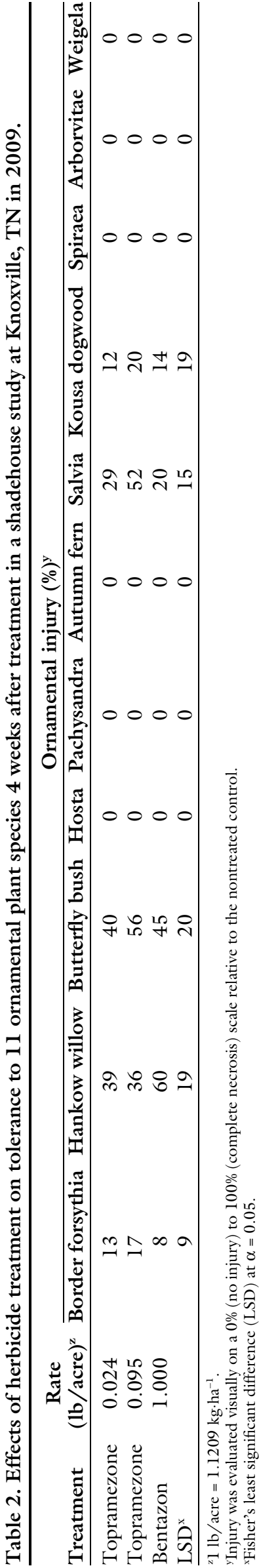

Salvia, hankow willow, and butterfly bush were all substantially injured (29\% to $56 \%$ ) by these topramezone treatments 4 WAT. Border forsythia and kousa dogwoods treated with topramezone at 0.024 and $0.095 \mathrm{lb} /$ acre were injured $\approx 12 \%$ to $20 \%$ with no differences detected between application rates. Across all species evaluated in the second study, injury with topramezone at $0.024 \mathrm{lb} /$ acre was less than the commercial standard bentazon at $1.0 \mathrm{lb} /$ acre. Similarly, Gettys and Haller (2009) reported that 'Cocktail Whiskey' begonia (Begonia semperflorens), 'Sun Devil Extreme' vinca (Catharanthus roseus), 'Million Gold' melampodium (Melampodium paludosum), and 'Super Elfin' impatiens (Impatiens walleriana) exhibited only modest response when treated with topramezone contaminated irrigation water. In their studies, begonia was the most tolerant species followed by impatiens with the greatest response observed on vinca and melampodium.

Weed control and dry weight varied because of herbicide treatment (Table 3) in Study 1. Mesotrione and tembotrione provided $67 \%$ to $100 \%$ control of redroot pigweed across the three application rates tested (Table 3). All rates of topramezone controlled redroot pigweed $93 \%$ or greater. Responses in the current study are similar to those reported by other researchers studying mesotrione, tembotrione, and topramezone efficacy for redroot pigweed control in agronomic crops (Bollman et al., 2008; Lamore et al.,
2006; Zollinger and Ries, 2006). All rates of tembotrione, topramezone, and mesotrione at $0.09 \mathrm{lb} /$ acre provided only $8 \%$ to $60 \%$ control of spotted spurge; however, when mesotrione rates were increased to $0.18 \mathrm{lb} /$ acre or higher, spotted spurge was controlled at least $93 \%$. Neither mesotrione nor tembotrione effectively controlled chamberbitter in this study and while topramezone exhibited the most activity on chamberbitter, control never exceeded $60 \%$. Bentazon did not provide adequate control of spotted spurge, redroot pigweed, or chamberbitter but did control yellow nutsedge $78 \%$. Similarly, mesotrione applied at $0.18 \mathrm{lb} /$ acre to $0.36 \mathrm{lb} /$ acre controlled yellow nutsedge $72 \%$ to $87 \%$. This response has been reported by other researchers following bentazon or mesotrione applications for yellow nutsedge control (Armel et al., 2008; Derr and Wilcut, 1993; Fretz and Sheppard, 1979; Pereira et al., 1987; Stoller et al., 1979).

In general, dry weights of weed biomass confirmed visual weed control ratings (Table 4). Mesotrione and bentazon were the only herbicides that reduced yellow nutsedge dry weight to less than $10 \mathrm{~g}$, which was $50 \mathrm{~g}$ less than the nontreated control. The dry weights of spotted spurge treated with mesotrione were significantly less than the nontreated spotted spurge; however, no other herbicide treatments significantly reduced the dry weight of spotted spurge. Generally, topramezone treatments reduced dry weights of redroot

Table 3. Effects of herbicide treatment on weed control in a container shadehouse study by 4 weeks after treatment at Knoxville, TN in 2008.

\begin{tabular}{|c|c|c|c|c|c|}
\hline \multirow[b]{2}{*}{ Treatment } & \multirow[b]{2}{*}{$\begin{array}{c}\text { Rate } \\
(\text { lb/acre })^{z}\end{array}$} & \multicolumn{4}{|c|}{ Weed control $(\%)^{\mathrm{y}}$} \\
\hline & & $\begin{array}{c}\text { Yellow } \\
\text { nutsedge }\end{array}$ & $\begin{array}{l}\text { Spotted } \\
\text { spurge }\end{array}$ & $\begin{array}{l}\text { Redroot } \\
\text { pigweed }\end{array}$ & Chamberbitter \\
\hline Mesotrione & 0.090 & 33 & 60 & 67 & 12 \\
\hline Mesotrione & 0.180 & 87 & 100 & 100 & 7 \\
\hline Mesotrione & 0.360 & 72 & 93 & 78 & 23 \\
\hline Topramezone & 0.016 & 18 & 25 & 93 & 42 \\
\hline Topramezone & 0.032 & 30 & 33 & 100 & 27 \\
\hline Topramezone & 0.064 & 12 & 58 & 98 & 63 \\
\hline Tembotrione & 0.080 & 10 & 23 & 78 & 15 \\
\hline Tembotrione & 0.160 & 23 & 10 & 80 & 40 \\
\hline Tembotrione & 0.320 & 57 & 8 & 100 & 17 \\
\hline Bentazon & 0.500 & 78 & 0 & 0 & 0 \\
\hline $\operatorname{LSD}_{0.05^{x}}$ & & 16 & 47 & 31 & 13 \\
\hline
\end{tabular}


Table 4. Effects of herbicide treatment on weed dry weight in a shadehouse study at Knoxville, TN in 2008.

\begin{tabular}{lccccc}
\hline & & \multicolumn{4}{c}{ Weed dry wt $(\text { gram/container })^{\mathrm{z}}$} \\
\cline { 3 - 6 } Treatment & $\begin{array}{c}\text { Rate } \\
(\mathbf{l b} / \text { acre })^{\mathrm{z}}\end{array}$ & $\begin{array}{c}\text { Yellow } \\
\text { nutsedge }\end{array}$ & $\begin{array}{c}\text { Spotted } \\
\text { spurge }\end{array}$ & $\begin{array}{c}\text { Redroot } \\
\text { pigweed }\end{array}$ & Chamberbitter \\
\hline Mesotrione & 0.090 & 43.60 & 0.53 & 1.94 & 0.84 \\
Mesotrione & 0.180 & 4.20 & 0 & 0 & 1.22 \\
Mesotrione & 0.360 & 21.44 & 0.11 & 0.45 & 1.48 \\
Topramezone & 0.016 & 67.86 & 1.92 & 0 & 0.55 \\
Topramezone & 0.032 & 39.30 & 1.21 & 0 & 0.33 \\
Topramezone & 0.064 & 78.47 & 1.32 & 0 & 0.75 \\
Tembotrione & 0.080 & 50.76 & 2.41 & 0.60 & 1.07 \\
Tembotrione & 0.160 & 46.90 & 2.83 & 0.67 & 1.16 \\
Tembotrione & 0.320 & 14.34 & 2.48 & 0 & 0.61 \\
Bentazon & 0.500 & 8.88 & 4.51 & 5.16 & 3.34 \\
Non-treated control & & 61.95 & 2.01 & 12.45 & 1.96 \\
LSD $_{0.05}{ }^{y}$ & & 18.7 & 1.45 & 3.65 & 0.9 \\
\hline
\end{tabular}

${ }^{\mathrm{z}} \mathrm{l} \mathrm{lb} / \mathrm{acre}=1.1209 \mathrm{~kg} \cdot \mathrm{ha}^{-1}, \mathrm{l} \mathrm{g}=0.0353 \mathrm{oz}$.

${ }^{y}$ Fisher's least significant difference (LSD) at $\alpha=0.05$.

pigweed and chamberbitter more than the other herbicide treatments, particularly when comparing the lowest herbicide rate applications.

\section{Conclusion}

Japanese holly and daylily were tolerant to all rates of mesotrione, topramezone, and tembotrione evaluated in this study. In addition, burning bush, hosta, pachysandra, autumn fern, spirea, arborvitae, and weigela were tolerant to topramezone at rates as high as $0.095 \mathrm{lb} /$ acre. Flowering dogwood, hankow willow, butterfly bush, salvia, and rose were injured by all HPPD-inhibiting herbicides evaluated in these studies. Topramezone was the only herbicide evaluated that provided at least $93 \%$ control of redroot pigweed across all rates evaluated. All HPPD-inhibitors provided poor control of chamberbitter $(\leq 63 \%)$ and only mesotrione applied at 0.09 $\mathrm{lb} /$ acre or higher provided significant activity on spotted spurge or yellow nutsedge. The commercial standard bentazon provided acceptable control of yellow nutsedge. Similar to responses reported by other researchers (Bachman et al., 1995; Derr and Appleton, 1987), bentazon was also safe $(0 \%$ to $10 \%$ injury) to all ornamental plants evaluated in the first experiment with the exception of rose and was found to be safe to six additional ornamental plant species in the second study.

The damage that untreated weed infestations inflict on nurseries can exceed \$7100 per acre annually (Hall et al., 2006). Therefore, it is important to incorporate new herbicide active ingredient in ornamental plant systems. Future research should include additional evaluations of tembotrione and topramezone on other ornamental plants and weeds of importance to the nursery and landscape industries. In addition, studies should be undertaken to understand the differential tolerance of ornamentals and weeds to HPPD-inhibitors applied in these environments.

\section{Literature cited}

Armel, G.R., H.P. Wilson, R.J. Richardson, C.M. Whaley, and T.E. Hines. 2008. Mesotrione combinations with atrazine and bentazon for yellow and purple nutsedge (Cyperus esculentus and C. rotundus) control in corn. Weed Technol. 22:391-396.

Atland, J.E., C.H. Gilliam, and G. Whetje. 2003. Weed control in field nurseries. HortTechnology 13:9-14.

Bachman, G., C. Wilson, and T. Whitwell. 1995. Tolerance of containerized landscape plants to the postemergence herbicides stinger, manage and basagran. J. Environ. Hort. 13:129-132.

Beam, J.B., W.L. Barker, and S.D. Askew. 2006. Selective creeping bentgrass (Agrostis stolonifera) control in cool season turfgrass. Weed Technol. 20:340-344.

Bollman, J.D., C.M. Boerboom, R.L. Becker, and V.A. Fritz. 2008. Efficacy and tolerance to HPPD-inhibiting herbicides in sweet corn. Weed Technol. 22:666-674.

Case, L.T., H.M. Mathers, and A.F. Senesac. 2005. A review of weed control practices in container nurseries. HortTechnology 15:535-545.
Derr, J.F. 1994. Weed control in container grown ornamentals. HortScience 29:95-97.

Derr, J.F. and B.L. Appleton. 1987. Phytotoxicity and yellow nutsedge control in azalea and liriope with basagran (bentazon). J. Environ. Hort. 7:91-94.

Derr, J.F. and J.W. Wilcut. 1993. Control of yellow and purple nutsedges in nursery crops. Weed Technol. 7:112-117.

Elmore, M.T., J.T. Brosnan, D.A. Kopsell, and G.K. Breeden. 2011. Methods of assessing bermudagrass responses to HPPD-inhibiting herbicides. Crop Sci. 51:2840-2845.

Fretz, T.A. and W.J. Sheppard. 1979. Evaluation of bentazon for yellow nutsedge (Cyperus esculentus) control in containergrown nursery stock. HortScience 14:71. (abstr.).

Gettys, L.A. and W.T. Haller. 2009. Tolerance of selected bedding plants to four herbicides in irrigation water. HortTechnology 19:546-552.

Giese, M.S., R.J. Keese, N.E. Christians, and R.E. Gaussoin. 2005. Mesotrione: A potential selective post-emergence herbicide for turfgrass, p. 100-101. In: Proceedings 10th Intl. Turfgrass Res. Conf. Llandudno, Wales, 10-15 July 2005. Intl. Turfgrass Soc. Aberystywth, UK.

Gilliam, C.H., W.J. Foster, J.L. Adrain, and R.L. Shumack. 1990. A survey of weed control costs and strategies in container production nurseries. J. Environ. Hort. 8:133-135.

Grossman, K. and T. Ehrhardt. 2007. On the mechanism of action and selectivity of the corn herbicide topramezone: A new inhibitor of 4-hydroxyphenylpyruvate dioxygenase. Pest Mgt. Sci. 63:429439.

Hall, C.R., A.W. Hodges, and J.J. Haydu. 2006. The economic impact of the green industry in the United States. HortTechnology 16:345-353.

Jackson, B.E., R.D. Wright, J.F. Browder, J.R. Harris, and A.X. Niemiera. 2008. Effect of fertilizer rate on growth of azalea and holly in pine bark and pine tree substrates. HortScience 43:1561-1568.

Jackson, D.P., C. Gillman, D. South, S. Enebak, and D.J. Eakes. 2009. Evaluation of four herbicides to control yellow nutsedge and assess seedling tolerance in loblolly and slash pine seedlings. Southern Nursery Assn. Res. Conf. 54:129133.

Johnson, C.R., D.L. Gunter, and J.T. Midcap. 1976. Planning production of container grown azaleas. Southern Nursery Assn. Res. J. 3:26-37. 


\section{Research Reports}

Jones, M.A. and N.E. Christians. 2007. Mesotrione controls creeping bentgrass (Agrostis stolonifera) in kentucky bluegrass. Weed Technol. 21:402-405.

Lamore, D.G., G. Simpkins, K. Watteyne, and J. Allen. 2006. Weed control programs with tembotrione in corn. Proc. North Central Weed Sci. Soc. 61:119. (abstr.).

Little, D.A., R.J. Richardson, and B.H. Zandstra. 2004. Response of four ornamental crops and selected weeds to mesotrione. Proc. North Central Weed Sci. Soc. 59:159. (abstr.).

Mathers, H. and E. Ozkan. 2001. Herbicide treated mulches. Nursery Mgt. Production 17:61-66.

Niyogi, K.K. 1999. Photoprotection revisited: Genetic and molecular approaches. Annu. Rev. Plant Physiol. Plant Mol. Biol. 50:333-359.

Norcini, J.G. and R.H. Stamps. 1994. Container nursery weed control. Univ. of Florida, Inst. Food Agr. Sci., Florida Coop. Ext. Serv. Circ. 678.

Pereira, W., G. Crabtree, and R.D. William. 1987. Herbicide action on purple and yellow nutsedge (Cyperus rotundus and Cyperus esculentus). Weed Technol. 1:92-98.

Senesac, A.F. 2002. Weed management in herbaceous perennials. Proc. Pennsylvania Landscape Nursery Conf. p. 17-22.

Senesac, A.F. and I. Tsontakis-Bradley. 2007. Phytotoxicity of granular mesotrione to ornamentals. I Feb. 2013. <http:// www.longislandhort.cornell.edu/pdfs / 2007_annual_reports/6_2007_research sum maries.pdf $>$.

Senseman, S.A. (ed.). 2007. Herbicide handbook. 9th ed. Weed Sci. Soc. Amer. Lawrence, KS.

Smith, C.N. and D.B. McConnel. 1978. Effects of changes in prices of selected production inputs on azaleas costs per container. Proc. Florida State Hort. Soc. 91:217-220.

Stoller, E.W., L.M. Wax, and F.W. Slife. 1979. Yellow nutsedge (Cyperus esculentus) competition and control in corn (Zea mays). Weed Sci. 27:32-37.

Vea, E. and C.L. Palmer. 2010. IR-4 Ornamental horticulture program mesotrione crop safety. IR-4 Project Headquarters, Rutgers-The State University of New Jersey, Princeton, NJ.

Willis, J.B., J.B. Beam, W.L. Barker, and S.D. Askew. 2006. Weed control options in spring seeded tall fescue (Festuca arundinacea). Weed Technol. 20:10401046.

Zollinger, R. and J.L. Ries. 2006. Comparing mesotrione, tembotrione, and topramezone. Proc. North Central Weed Sci. Soc. 61:114. (abstr.). 